\title{
“NÃO É NENÊ, ELA É PRETA": EDUCAÇÃO INFANTIL E PENSAMENTO INTERSECCIONAL
}

\author{
FLAVIO SANTIAGO ${ }^{1}$ \\ ORCID: https://orcid.org/0000-0001-7019-2042
}

\begin{abstract}
RESUMO: O artigo tem como objetivo contribuir com os estudos da Educação Infantil, explorando as intersecções entre o processo de racialização e as relações de gênero, idade e classe social estabelecidos no cotidiano de uma creche pública que atende crianças de 0 a 3 anos. Trata-se de uma etnografia realizada na região metropolitana de Campinas (SP), ao longo de um ano, fazendo uso do registro em caderno de campo e de entrevistas com as docentes da unidade. Com base nas análises, pode-se destacar que as crianças, em muitos momentos, reproduzem as hierarquias pautadas na ordem patriarcal e racista, bem como que existem práticas pedagógicas sexistas-racistas na creche.
\end{abstract}

Palavras-chave: Intersecção, Racismo, Relações de gênero, Creche. Sociologia da Infância

\section{“IT’S NOT BABY, SHE'S BLACK": CHILD EDUCATION AND INTERSECTIONAL THINKING}

\begin{abstract}
This article aims to contribute to the studies related to Early Childhood Education, exploring the aspects related to the intersections between the process of racialization, the relations of gender, age, and social class established in the routine of a public daycare center that serves children aged 0 to 3. It is an ethnography carried out in the metropolitan region of Campinas-SP in the course of one year, making use of a field notebook for record purposes, and interviews with the teachers of the unit. Based on the analyses, it can be noted that children often reproduce hierarchies based on the patriarchal and racist order, as well as there are sexist-racist pedagogical practices in the daycare center.
\end{abstract}

Keywords: Intersection, Racism, Gender Relations, Daycare Center, Sociology of childhood

\section{“NO ES BEBÉ, ES NEGRA”: EDUCACIÓN INFANTIL Y PENSAMIENTO INTERSECCIONAL}

RESÚMEN: Este artículo tiene como objetivo contribuir a los estudios de educación de la primera infancia, explorando las intersecciones entre el proceso de racialización y las relaciones de género, edad y clase social establecidas en la vida diaria de una guardería pública que atiende a niños de 0 a 3 años. Esta es una etnografía llevada a cabo en la región metropolitana de Campinas (SP) durante un año, utilizando un cuaderno de campo para registro y entrevistas con los maestros de la unidad. Con base en el análisis, se puede resaltar que los niños, en muchos momentos, reproducen las jerarquías basadas en el orden patriarcal y racista, así como existen prácticas pedagógicas sexistas-racistas en la guardería.

Palabras clave: Intersección. Racismo. Relaciones de género. Guardería. Sociología de la infancia.

\footnotetext{
${ }^{1}$ Prefeitura Minicipal de Ribeirão Bonito, SP - Brasil. <santiagoflavio2206@gmail.com>
} Educação em Revista|Belo Horizonte|v.36|e220090|2020 


\section{INTRODUÇÃO: INTERSECÇÃO E INFÂNCIAS}

Este artigo busca contribuir com os estudos da Educação Infantil, explorando as intersecções entre o processo de racialização e as relações de gênero, idade e classe social estabelecidos no cotidiano de uma creche pública que atende crianças de 0 a 3 anos, na região metropolitana de Campinas (SP) ${ }^{2}$.

A ideia de intersecção sugere relações de conexão que, segundo Brah (2006), devem ser construídas como historicamente contingentes e específicas de determinada conjuntura. A partir desse recorte, é possível focalizar dado contexto e definir demarcações para a construção do objeto como categoria analítica e como tema de mobilização política e de pesquisa. Ligado à teoria crítica de raça, o conceito de interseccionalidade foi cunhado por Kimberlé Crenshaw, e ganhou popularidade após a Conferência Mundial contra Racismo, Discriminação Racial, Xenofobia e Formas Conexas de Intolerância em Durban, na África do Sul, em 2001.

Atualmente a interseccionalidade tem ganhado expressividade, contudo, é importante destacar que a preocupação em relação ao entrelaçamento entre as categorias raça, gênero, classe social e sexualidade tem sido foco dos debates promovidos por feministas negras, as quais procuraram, desde a construção do processo abolicionista, construir uma luta articulada não apenas contra a opressão sexual das mulheres, mas também contra outras formas de dominação e desigualdade baseadas no racismo. Como ressaltou Nilma Limo Gomes (2017, informação verbal) ${ }^{3}$, na mesa-redonda "Mulheres negras, resistências e interseccionalidades", no $13^{\circ}$ Congresso Mundial de Mulheres \& Seminário Internacional Fazendo Gênero 11, a articulação da categoria interseccionalidade

denuncia e anuncia algo mais profundo do que só saber lidar e articular as nossas diferenças de raça, classe, gênero, sexualidades, aflições, as formas como são hierarquizadas na sociedade. A interseccionalidade, na minha perspectiva, ela denuncia também o quanto esses sistemas perversos são estruturais e são estruturantes. Como eles são a raiz da opressão, do pensamento inferiorizante e violento, e retiram as negras e os negros do lugar de humanidade.

O debate acerca das intersecções se insere no desafio de compreender a gênese da transformação de diferenças em elementos para justificar as desigualdades criadas pelo sistema capitalista, que privilegia um padrão de homem, de mulher, de sociedade e de sujeito social. Como destaca Akotirene (2018, p. 39), "a interseccionalidade nos instrumentaliza a enxergar a matriz colonial moderna contra os grupos tratados como oprimidos [...]". E o processo de diferenciação de grupos humanos com base em atributos classificatórios é a marca da narrativa da história ocidental. Desse modo, pesquisar as intersecções entre as relações de gênero e o processo de racialização não representa um tema novo para a educação, mas o desafio político de compreender como são estabelecidas as diferenciações entre os sujeitos por meio do contexto cultural e social (ROSEMBERG, 1996).

As teorias feministas interseccionais, para Ianniciello (2015), constituem uma alternativa revolucionária, porque são baseadas no reconhecimento do posicionamento subjetivo como ponto de partida analítico com todas as suas variantes de gênero, classe, raça, geografia, produzindo um conhecimento em que a consideração da singularidade encarnada e da subjetividade minoritária torna-se uma instância crítica em relação à ideia de sujeito. Assim,

A interseccionalidade inicia um processo de descoberta, nos alertando para o fato de que o mundo a nossa volta é sempre mais complicado e contraditório do que nós poderíamos antecipar. [...] Ela não provê orientações estanques e fixas para fazer a investigação feminista [...]. Ao invés disso, ela estimula nossa criatividade para olhar

\footnotetext{
${ }^{2}$ A pesquisa que dá base a este artigo foi apoiada financeiramente pela Fundação de Apoio à Pesquisa do Estado de São Paulo (FAPESP)/CAPES, pelo fomento ao processo n $n^{\circ}$ 2015/02464-0 que incluí uma Bolsa Estudos e Pesquisa no Exterior (BEPE), processo n ${ }^{\circ} 2016 / 25474-3$.

3 Anotações e gravação realizadas em 01 de agosto de 2017, em Florianópolis. Educação em Revista|Belo Horizonte|v.36|e220090|2020
} 
para novas e frequentemente não ortodoxas formas de fazer análises feministas. A interseccionalidade não produz uma camisa de força normativa para monitorar a investigação [...] na busca de uma "linha correta". Ao invés disso, encoraja cada acadêmica feminista a se envolver criticamente com suas próprias hipóteses seguindo os interesses de uma investigação feminista reflexiva, crítica e responsável. (DAVIS, 2008, p. 79)

Diante desse quadro, o centro das preocupações neste artigo é a necessidade de pensar as crianças pequenininhas, negras e brancas, enquanto sujeitos sociais localizados em um contexto social marcado pela diferenciação racial, de gênero e de idade. A infância não pode mais ser pensada de forma abstrata.

Torna-se fundamental conceituá-la de modo interseccionado, para compreendermos a gênese da transformação de diferenças em elementos para justificar as desigualdades criadas pelo sistema capitalista, que privilegia um padrão de sociedade e de sujeito e sem dúvida excluem a/o cidadão de pouca idade (cf. BENJAMIN, 1984). Cabe urgente falar em interseccionalidade entre raça/etnia, classes sociais, gênero e idade. (SANTIAGO; FARIA, 2018, p. 261).

As categorias classe social, gênero e etnia/raça se entrelaçam com a categoria idade, que expressa aqui a importância de pensar a infância no âmbito das intersecções, gerando conflitos advindos do sistema patriarcal, racista, adultocêntrico, e produzindo múltiplas desigualdades e hierarquizações.

Assim, as crianças não são "sujeitos desligados" dos emaranhados de diferenciação, identificação e estratificação social, constituindo-se enquanto meninas, meninos, negras, brancas, filhas/os de trabalhadoras ou herdeiras/os de grandes impérios do capital. Esse movimento permite aguçar nossos sentidos para perceber as crianças pequenininhas como agentes de transformação social, de modo a "não reduzir a capacidade de expressão das crianças somente à fala, mas de se estar atento aos gestos, movimentos, emoções, sorrisos, choros, silêncios, olhares, linguagens sonoras e outras linguagens" (PRADO, 1999, p. 111).

Nesse momento, destaca-se a percepção de que as crianças pequenininhas são construtores e construtoras de transformação social:

A ideia de que as crianças têm suas próprias culturas pode parecer exagerada para alguns leitores. Mas, as crianças podem sentir-se desconfortáveis na cultura adulta e até mesmo ser resistentes a ela, como parece ocorrer muitas vezes nas sociedades norte-americana e do norte da Europa, diante do referencial descritivo que ainda é a tradição cultural dominante. E eis aí o atrito. É um lugar-comum agora a ideia de que os ambientes culturais são múltiplos. $\mathrm{O}$ ambiente cultural que um indivíduo habita pode se tornar fragmentado, fluido, agitado e negociável - seja da perspectiva das informações ou do poder. Todos os ambientes culturais são compostos por ambientes subculturais concorrentes, múltiplos e conflituosos. O reconhecimento de que a cultura infantil é um deles não deveria apresentar nenhuma dificuldade a priori. Na verdade, para muitos estudiosos, isso não é realmente um problema (CORSARO, 1997; GOODWIN, 1990; as contribuições de JAMES;PROUST, 1990; MALTZ;BORKET, 1986; OPIE;OPIE, 1960; ver também ECKERT, 1989; WILLIS, 1981). Obviamente, as crianças não só vivem nas esferas culturais dos adultos com quem partilham suas vidas, mas elas criam e mantêm ambientes culturais próprios (HIRSCHFELD, 2016, p. 183).

As crianças pequenininhas, negras e brancas ${ }^{4}$, não são apenas produzidas pelas culturas, mas também produtoras de cultura. As diferenças entre os meninos pequenininhos e as meninas pequenininhas, e entre elas e eles e os/as adultos/as não são quantitativas, mas qualitativas. A criança

\footnotetext{
${ }^{4} \mathrm{Na}$ CEMEI pesquisada, não havia crianças indígenas, por isso no decorrer do artigo serão mencionadas apenas as crianças negras e brancas. Destaca-se que as crianças indígenas também são sujeitos ativos na sociedade, sendo atores e atrizes sociais Educação em Revista|Belo Horizonte|v.36|e220090|2020
} 
não sabe menos; sabe outras coisas (COHN, 2005). Podemos ainda observar que "as crianças desde muito pequenas aprendem a 'ler no corpo' (HALL, 1992) as diferenças raciais e a verbalizá-las e, no limite, rejeitá-las" (ABRAMOWICZ; CRUZ; RODRIGUES, 2017, p. 17).

Florestan Fernandes, no texto intitulado As trocinhas do Bom Retiro: contribuições ao estudo folclórico e sociológico da cultura e dos grupos infantis, de 1944, escreve:

Os próprios imaturos também elaboram, é obvio, parte dos elementos de seu patrimônio cultural. Alguns desses elementos foram, mesmo, estruturados sobre moldes fornecidos pela vida interativa da "gente grande". Essas criações, todavia, se institucionalizaram, posteriormente, podendo ser aprendidas nos grupos infantis, como acontece com os elementos aceitos da cultura do adulto. (FERNANDES, 2004, p. 216)

As culturas infantis são produzidas por meio das diferentes relações que as crianças estabelecem com o mundo, trazendo também para suas construções os conflitos existentes nos espaços em que convivem, o que é extremamente positivo. Ao encontro do pensamento de Fernandes ([1944] 2004), mas em continente e momento histórico diferentes, Corsaro (2011) propõe o conceito da reprodução interpretativa para pensar a produção das culturas infantis. O termo interpretativo abrange os aspectos inovadores e criativos da participação infantil na construção da realidade social, destacando as formas particulares das crianças de criar e participar das culturas de pares ${ }^{5}$, não se limitando a internalizar a sociedade e a cultura, mas contribuindo ativamente para a produção e mudança cultural. $\mathrm{O}$ termo reprodução aponta também para o fato de que as meninas e os meninos estão restritos pelas estruturas sociais existentes, ou seja, as infâncias e as produções das crianças são afetadas diretamente pela cultura e sociedade que integram e, em alguma medida, reproduzem.

A pesquisa com crianças pequenininhas constitui-se um grande desafio, tanto para as pesquisadoras e os pesquisadores, quanto para as estruturas rígidas e monossilábicas da epistemologia eurocentrada (SANTOS, 2010). Esse desafio é posto porque aprendemos, em todo o percurso escolar, bem como nos manuais de pesquisa científica, a pensar de modo linear, binário e cartesiano. Quando chegamos ao campo, encontramos meninos pequenininhos e meninas pequeninhas transbordando a sua intempestividade criativa, rabiscando as produções das relações sociais com seus pensamentos dialéticos.

\section{O ESPAÇO E O TEMPO DA REALIZAÇÃO DA PESQUISA: ENCONTROS ETNOGRÁFICOS}

A partir dos pressupostos apresentados, considera-se a Etnografia um instrumento metodológico relevante para compreender um pouco da intempestividade criativa das crianças pequeninhas, proporcionando encontros de diferentes naturezas: afetiva, sensorial, social e cultural. Os cheiros, as cores, os sons tornam-se elementos frutíferos na construção da pesquisa, pois representam dados fecundos para a compreensão das relações que os sujeitos estabelecem e das construções das culturas infantis.

$\mathrm{Na}$ busca por conhecer instituições de Educação Infantil para a realização da pesquisa, foram delimitados alguns critérios: pertencer à rede pública, possuir projetos relativos à temática das diferenças étnico-raciais e de gênero, e conter em seu histórico a disponibilidade em receber pesquisadores(as). Dessa forma, foi possível elencar nomes de instituições de Educação Infantil da região metropolitana de Campinas que poderiam me receber. Também foram pensadas estratégias de como chegar à equipe gestora da instituição para solicitar autorização, e quais procedimentos éticos deveriam ser seguidos para a escolha do grupo acompanhado na realização da pesquisa.

Dentre as indicações, selecionei três creches com localização acessível por meio de transporte público. A partir daí, iniciei o contato com as unidades, primeiramente por meio do correio eletrônico e, posteriormente, via telefone. Entre as creches consultadas, somente uma se disponibilizou

\footnotetext{
5 Termo utilizado por Corsaro em inglês: peer culture. 
a me receber e conhecer o projeto. As outras indicaram que isso não seria possível, pois já tinham pesquisadores/as realizando trabalhos na unidade ou não estavam interessadas em participar da pesquisa.

Em um primeiro momento, marquei uma reunião com a orientadora pedagógica da unidade, que se disponibilizou a me receber para a apresentação do projeto, da metodologia utilizada e de possíveis implicações para a rotina da unidade. Nesse momento, também deixei uma cópia do projeto de pesquisa com a equipe gestora.

Após essa conversa, a orientadora pedagógica apresentou a proposta às docentes, que decidiram coletivamente pelo aceite da realização da pesquisa. A partir daquele momento, todas as medidas diante do Comitê de Ética em pesquisa da UNICAMP foram tomadas, sendo emitido, no dia 2 de fevereiro de 2016, o parecer número 1.400.323, que respalda a ética dos procedimentos metodológicos do projeto de pesquisa ${ }^{6}$. Os nomes das docentes foram substituídos por nomes de origem africana, em homenagem à cultura e história dos povos africanos. Os nomes das crianças pequenininhas também foram trocados, sendo escolhidos a partir de nomes de escritoras e escritores negros/negras brasileiros(as) e africanos(as), como outra forma de homenagem.

A aceitação das crianças pequenininhas, negras e brancas, também foi fundamental, e não se expressou pelo termo de livre consentimento assinado pelos/as seus/suas responsáveis legais, mas pelo olhar carinhoso expresso quando me viam chegar, nos abraços de acolhimento, no convite baixinho para eu escutá-las, ou por simples pedidos como o feito aos pés de um balanço do parque: "Me balança bem forte! De novo! De novo!”.

A instituição de Educação Infantil na qual a pesquisa de campo foi realizada é identificada como Centro Municipal de Educação Infantil (CEMEI) e atende crianças de 0 a 5 anos. Possui agrupamentos I e II em período integral, e agrupamento III em período parcial. O agrupamento I é formado por crianças de 0 a 1 ano e 6 meses; o agrupamento II é formado por crianças de 1 ano e 6 meses até 4 anos e 1 mês, e o agrupamento III é formado por crianças de 4 anos e 1 mês até 5 anos.

A CEMEI possui duas salas de agrupamento I, três de agrupamento II e seis de agrupamento III. A pesquisa aqui descrita foi realizada com crianças dos agrupamentos I e II, contudo nessa sala em específico não havia nenhuma criança com 4 anos nessa turma; a mais velha iria completar 4 anos em dezembro, final do ano letivo. Os agrupamentos I e II, que funcionam em período integral, contam com três profissionais no período da manhã e três profissionais no período da tarde; em cada grupo, há uma formada em Pedagogia, considerada a professora da sala, e duas com formação em nível médio, consideradas monitoras. Já os agrupamentos III têm somente uma docente, com formação em nível superior. Considero todas as profissionais que atuam com as crianças docentes, uma vez que ocupam o cargo de professora ou monitora.

Ao longo da pesquisa, constatei a rotatividade constante de algumas monitoras, por diversos motivos, por isso sempre havia uma nova figura na turma; muitas vezes, nem mesmo a equipe sabia quem seria a monitora presente no dia, o que comprometia o andamento de projetos e a própria união da equipe responsável pela turma de crianças.

O bairro em que o CEMEI está localizado é distante do centro da cidade e apresenta diversidade econômica e racial; possui rede de saneamento básico, residências de padrão popular e pequenos comércios, e está nas proximidades da rodovia Santos Dumont (SP-075).

Com relação à arquitetura, possui amplos espaços externos destinados às brincadeiras das crianças; as salas também são amplas. A cada dia, uma das turmas do CEMEI ocupa um espaço externo, em rodízio; toda turma fica em um ambiente em dia específico da semana. Em alguns momentos, há encontros entre as turmas nesses espaços, propiciando a interação entre diferentes idades, e também a produção de novos arranjos entre os grupos de crianças e a criação de novas brincadeiras ${ }^{7}$.

\footnotetext{
6 “[...] elemento paradoxal é a ética da relação com as crianças na pesquisa, isso porque se partimos do pressuposto que as crianças são as melhores informantes das questões que lhes dizem respeito e que seu ponto de vista deve ser considerado, inclusive sobre a sua disponibilidade de ser ouvida, como procedemos quando se trata de crianças bem pequenas, que não utilizam a fala como principal forma de comunicação? A não utilização da fala não abstém os adultos da responsabilidade de identificar a disponibilidade, ou não, das crianças para a participação nas pesquisas" (COUTINHO, 2016, p. 765).

${ }^{7}$ A respeito desses encontros e possibilidades de construção de novas brincadeiras, cf. Prado (1999). Educação em Revista|Belo Horizonte|v.36|e220090|2020
} 
Consegui, por meio das fichas de matrícula das crianças, construir um perfil de características socioculturais das famílias das crianças pequenininhas negras e brancas, atentando para o fato de que as configurações são diversas. As famílias atendidas pela unidade possuem, de maneira geral, renda familiar de um a dois salários mínimos, sendo a maioria dos responsáveis empregada em postos de trabalho nos comércios da cidade. Entre aqueles que exercem atividades remuneradas fora de casa, a maior parte tem horário de trabalho das 8 às 17 horas. Com relação ao nível de escolaridade dos/as responsáveis pelas crianças, predomina o Ensino Médio completo; poucos/as têm nível superior.

Com base nos dados do projeto pedagógico do CEMEI, verifica-se predominantemente que o pertencimento racial das crianças é branco e que o sexo é masculino. Os dados tomam como sistema de classificação o construído pelo IBGE; esta categorização reflete um conhecimento científico cristalizado (a relação entre raças e continentes geográficos) e a ideologia de classificação social com base na raça. $\mathrm{Na}$ sociedade brasileira, a cor é a metáfora, a categoria mais frequentemente acionada para demarcar diferenças e desigualdade com base na raça. Raça aqui concebida como um fator social, referida aos significados atribuídos pelas pessoas a atributos físicos e que servem para demarcar indivíduos e grupos, como uma percepção social que categoriza. (ARAUJO, 1987, p. 15)

A partir desse pressuposto, podemos observar o gráfico 1.

Gráfico 1 - Dados de sexo/cor das crianças do CEMEI

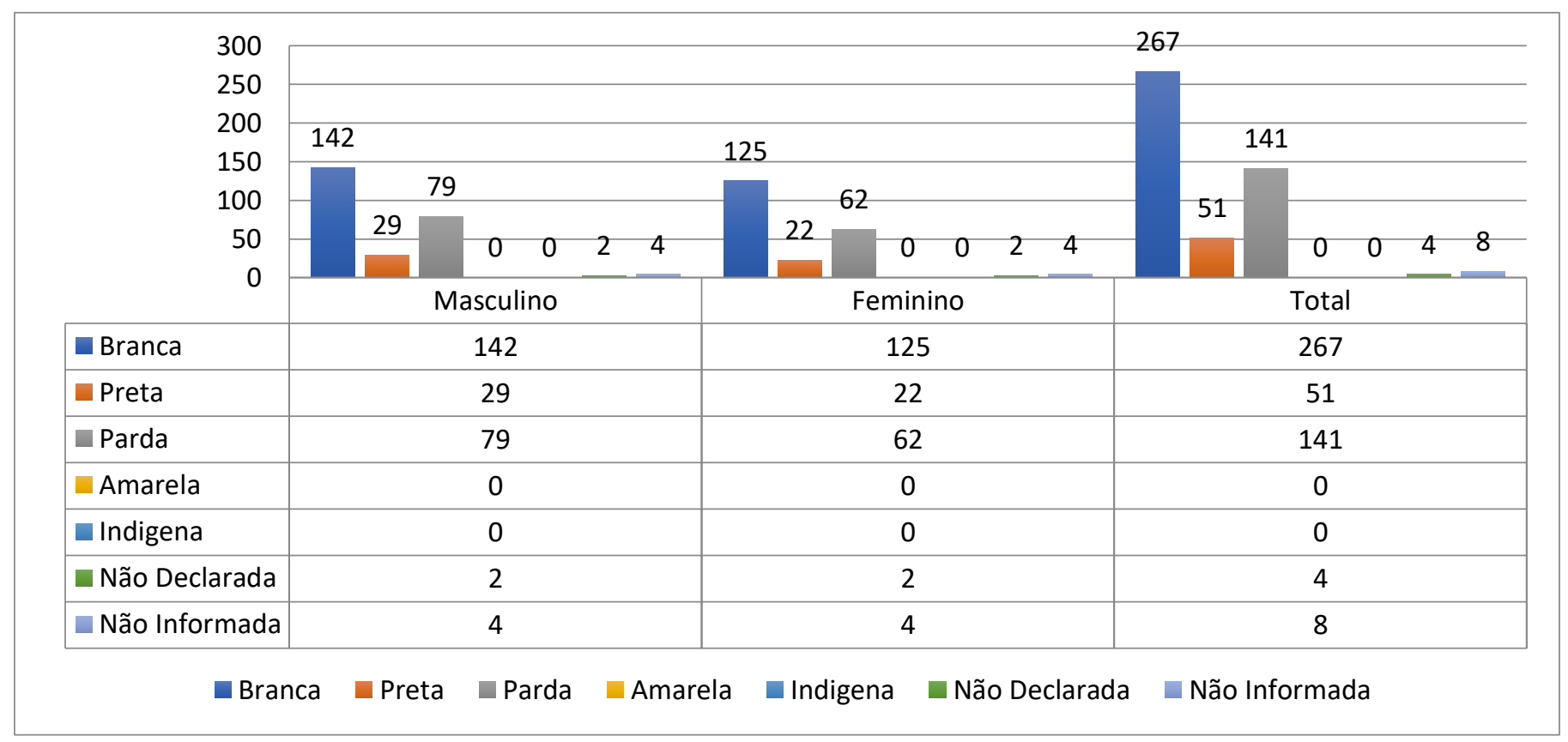

Fonte: ficha de matricula das crianças

A configuração das duas salas que acompanhei é observada nos gráficos 2 e $3^{8}$.

\footnotetext{
${ }^{8}$ Os dados são relativos ao início do período letivo. No decorrer do ano esses números tiveram muitas variações, devido à entrada de crianças por ordem judicial e à saída de outras meninas e outros meninos.

Educação em Revista|Belo Horizonte |v.36|e220090|2020
} 
Gráfico 2 - Dados de sexo/cor das crianças do agrupamento I

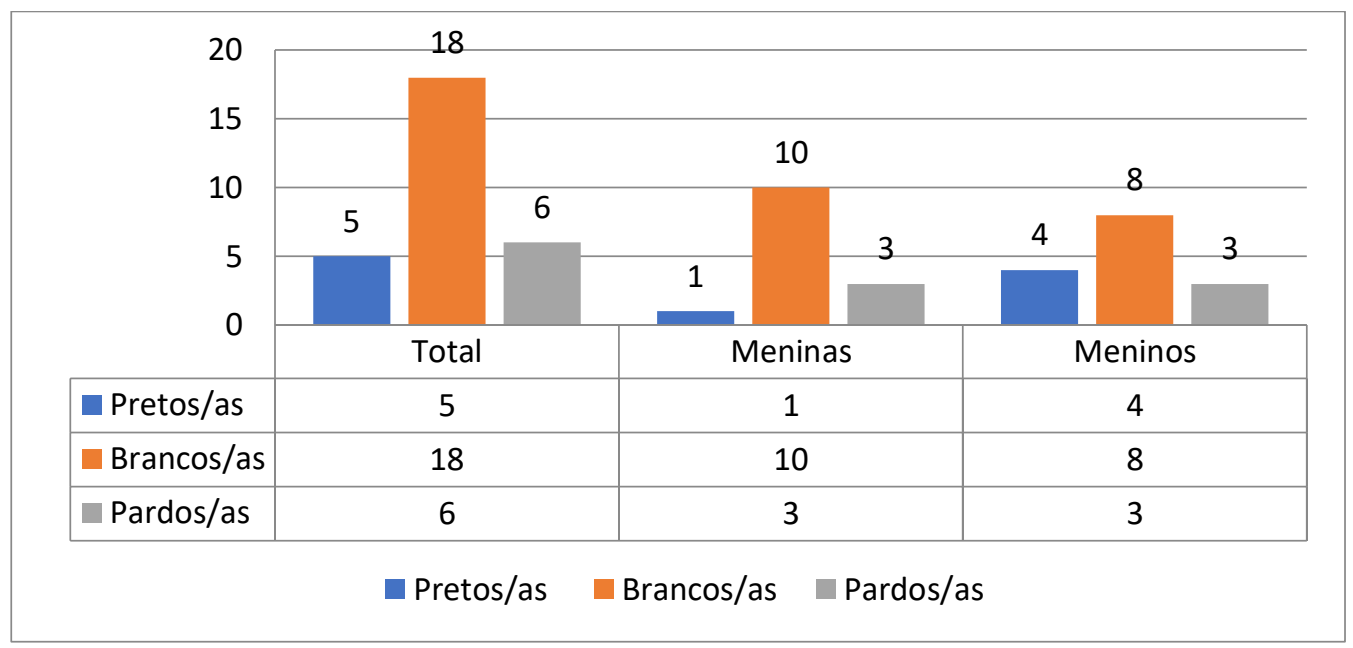

Fonte: ficha de matricula das crianças

Gráfico 3 - Dados de sexo/cor das crianças do agrupamento II

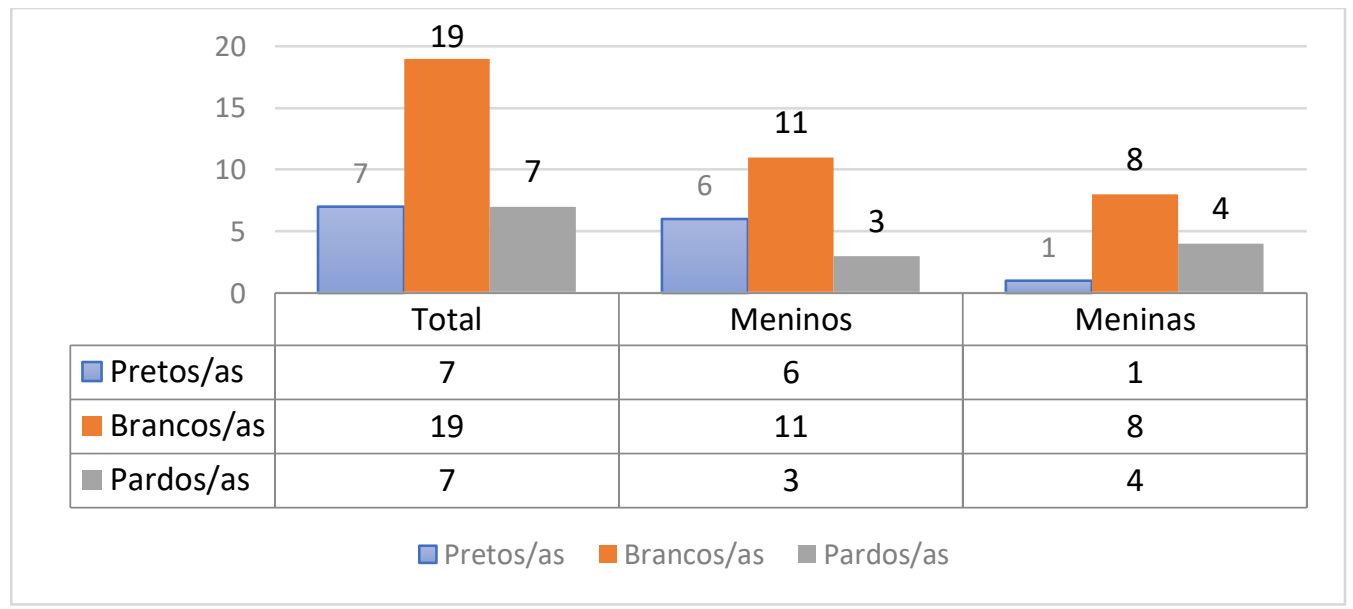

Fonte: ficha de matricula das crianças

Os dados apresentados de raça/cor das crianças pequenininhas têm como característica a heteroidentificação; esse procedimento é "naturalizado", o que faz parecer normal que a declaração de cor e/ou raça de crianças seja definida por seus pais, mães ou outros adultos por elas responsáveis, criando o imaginário de que crianças assim serão "preservadas" do debate acerca das relações raciais (ROSEMBERG, 1996; ROCHA; ROSEMBERG, 2007). Ainda assim, é importante apresentar esses dados, pois, como aponta Nunes (2016, p 408), as "crianças vivem numa sociedade que, por mais que não se queira ver racializada, mantém uma série de ações e atividades que denotam que este marcador é utilizado para definir lugares e espaços". Em nossa sociedade racializada, a cor se transforma em raça em situações sociais como as que qualificam o negro como feio, ou brincadeiras com posições e hierarquias

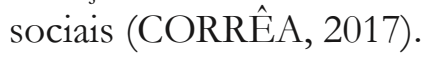


[...] no uso burocrático e popular, o termo cor substitui o de raça, mas deixou à mostra todos os elementos das teorias racistas - cor, no Brasil, é mais que cor de pele: na nossa classificação, a textura do cabelo e o formato de nariz e lábios, além de traços culturais, são elementos importantes na definição de cor (preto, pardo, amarelo e branco). (GUIMARÃES, 2011, p. 266)

No Brasil, vivemos grandes marcas da desigualdade deixadas pelo legado da escravidão, constituindo verdadeiras hierarquias na estrutura social. Muitas vezes, quando os/as responsáveis pelas crianças declaram uma criança de pele negra clara como branca ou parda não somente reproduzem a lógica da colonialidade pautada na branquitude, mas também, em certa medida, procuram proteger o menino pequenininho ou a menina pequenininha das mazelas do racismo de marca presente no contexto cultural (NOGUEIRA, 1955; TRINIDAD, 2011).

A partir dessa perspectiva, raça e racismo podem ser pensados como fenômenos ativos, capazes de determinar fatores econômicos e regular as relações sociais (MELLINO, 2016). Contudo, as questões relativas ao racismo e à raça são resíduos arcaicos e anacrônicos de uma narração colonial da história pautada numa lógica eurocentrada de expropriação e opressão de determinados grupos com base na desumanização do outro. Assim, as intersecções existentes entre as relações de gênero, raciais, de classe e etárias são estruturantes da dinâmica capitalista e permanecem nas suas configurações, construindo relações sociais e localizando os sujeitos na sociedade (SAFFIOTI, 1997; CRENSHAW, 2002; SANTIAGO, 2015).

O corpo biológico humano com a epiderme negra é igual ao corpo biológico humano com a epiderme caucasiana; os valores e signos criados sobre ele resultam de um processo de abstração fruto das relações culturais e do meio sócio-histórico em que está inserido (MBEMBE, 2014). A classificação e as tipificações, como apontam Alietti e Padovan (2000), são usadas para suspender a dúvida a respeito das "peculiaridades" e incertezas que afligem a vida cotidiana, numa situação de hierarquização entre grupos; esses argumentos dizem respeito a aspectos não biológicos, mas socioculturais.

Entretanto, esse mecanismo não é mero preconceito. Sua força depende sobretudo das hierarquias, do sistema de privilégios e da violência material dos quais é veículo, e não se constitui simplesmente como estereótipo. As sociedades racistas se formam precisamente a partir da proliferação de espaços e nichos altamente hierarquizados e racializados que, de alguma forma, transcendem a vontade e a subjetividade de indivíduos e grupos (CURCIO; MELLINO, 2012).

Os/as negros/as, tanto de pele escura quanto de pele clara, foram sempre projetados aos estratos das pessoas mais pobres, que não partilham (ou partilham muito pouco) das tendências do desenvolvimento econômico e da mudança sociocultural (FERNANDES, 2008). O ideal de imposto pelo universo criado pelos brancos marca a vida dos indivíduos negros/as nos âmbitos social, subjetivo e cultural; esse fenômeno impõe um movimento constante de busca por um padrão de brancura, acionando diferentes mecanismos - modificações corporais, limitação no uso de roupas, desenraizamento cultural - na tentativa de se enquadrar em um mundo branco para acessar privilégios destinados às pessoas brancas.

As meninas pequenininhas sofrem um processo de branqueamento maior, pois a própria construção do gênero feminino é estabelecida com base na passividade que se modula ao contexto patriarcal vigente. Como destaca Belotti (1987), a construção social do que é ser uma menina exige uma redução forçada de sua agressividade, efetuada por mudanças da textura do cabelo, pela escolha de posturas aceitas socialmente, bem como por rituais tranquilizadores que servem como refúgio para as vítimas de repressões maciças por causa de vitalidade, curiosidade e mobilidade consideradas excessivas. Um exemplo de método de "docilização" pode ser observado na pesquisa realizada por Abramowicz (2001) com meninas repetentes que falam pouco e rebelam-se pouco ao repetir de ano; ao fracassar em sua escolaridade, aproximam-se do trabalho doméstico, do qual outras mulheres procuram se libertar.

Talvez por conta dessas prerrogativas, muitas famílias declaram as meninas pequenininhas com um tom mais claro que o de suas peles. A instituição em que realizei a pesquisa possuía um número maior de meninos negros pequenininhos do que de meninas negras pequenininhas. O processo de construção social e cultural da feminilidade em muitos momentos impõe a passividade e emoldura 
normas sociais com maior rigor para as mulheres e meninas, influenciando diretamente o não reconhecimento da ancestralidade negra, bem como forçando um branqueamento e desenraizamento das suas origens.

Estes fatos, assim como olhares, palavras, gestos, cotidianamente são dirigidos a pessoas negras, indígenas, pessoas ciganas, a pessoas empobrecidas. E fazem com que cada pessoa, e notadamente as crianças, se deem conta de que a sociedade lhes reserva certos lugares, oportunidades, direitos, e as exclui de outros. Então haveria um lugar, haveria uma humanidade que não pertence a todos. Preconceitos sobre os quais se constrói a nação brasileira continuam cultivando sentimentos e ideias de que para pertencer à humanidade é preciso ser descendente de europeus ou é preciso ser branco. Quem for branco ou quanto mais branco, mais humano seria. (SILVA, 2015, informação $\operatorname{verbal}^{9}$ )

Para Fernandes (2008), que entende classe e raça como totalmente associadas no Brasil, é possível observar três movimentos de representação estereotipada da população negra: o primeiro é a representação do/a negro/a como etimologicamente inferior ao branco, em um processo de "folclorização" da cultura negra o qual cria imagens negativas dos elementos simbólicos que a compõem, como as religiões de matriz africana. O segundo movimento diz respeito à criação de uma imagem do/a negro/a como biologicamente superior ao branco, em um processo de adorno exacerbado de sua sexualidade, bem como de ligação direta de sua força física com o mundo do trabalho. $\mathrm{O}$ último movimento diz respeito à apresentação do/a negro/a como socialmente inferior ao/à branco/a, instituindo a imagem de uma bestialidade da população negra. Esse movimento tem como gênese a situação histórica da escravidão, que reforçou a imagem de inferioridade do/a negro/a, e justificava sua submissão e seu emprego como cativo/a.

A exemplo desse processo, Harbuu, docente negra, que me concedeu entrevista para a pesquisa, apresenta que muitas vezes as crianças brancas têm privilégios em relação às outras:

Loirinho, lourinha, do olho claro tem tratamento diferenciado. Aqui é nítido: "Você vai dar banho?", "Por que ela tem que tomar banho?", "Ela não precisa tomar banho". Algum tempo depois, a criança sai banhada, com o cabelo arrumado. Aí eu pergunto: "Por que deu banho nela? Agora dá banho naquela dali, ó". Porque só a criança loira tem esse privilégio. "Essa criança não precisa tomar banho aqui na escola. Ela toma banho todo dia na casa dela. Agora tem outro aqui, em sua maioria negros, que tava precisando tomar um banho. Por que você não deu?" Você só deu naquela criança loirinha. É assim... é... o negócio é... não é velado... é escancarado o negócio. (informação verbal, Harbuu - docente negra)

A classificação dos sujeitos pelo seu fenótipo fundamenta o preconceito de marca, que "toma por pretexto para as suas manifestações os traços físicos do indivíduo, a fisionomia, os gestos, o sotaque" (NOGUEIRA, 1955, p. 34). Dessa forma, o racismo se infiltra em todos os espaços, ecoando ideias que mutilam possibilidades de existência e construindo vidas encarceradas dentro de uma sobrevivência subalterna. Para a efetivação desse processo, inúmeras ações cotidianas adensam estereótipos, fixando destinos preestabelecidos para as crianças negras pequenininhas, as mulheres negras e os homens negros.

Esse tipo de percepção constrói um ideário racista que nasce quando se propõem características biológicas como justificativa de desigualdades e comportamentos. Assim, a desigualdade já inerente a qualquer sociedade estratificada em classes sociais foi reforçada pela hierarquia racial (FERNANDES, 2008) e pelo patriarcado. Podemos verificar tal fato nas anotações do meu diário de campo (abril de 2016):

\footnotetext{
${ }_{9}^{9}$ Petronilha Beatriz Gonçalves e Silva, na mesa-redonda "Entre os tratados coloniais e a emancipação humana: a luta pelo reconhecimento das diferenças", do II Seminário Internacional sobre Infâncias e Pós-colonialismo: Pesquisas em busca de pedagogias descolonizadoras, realizado em Campinas em 26 de outubro de 2015. 
As crianças pequenininhas estavam chegando à creche. Eu estava perto da estante de brinquedos, enquanto as observava entrar na sala e começar a se organizar nos grupos de brincadeiras. Carolina (menina negra pequenininha) se aproxima de mim com uma boneca negra nos braços e me entrega. Sem hesitar, pergunto para ela:

- É a nenê? Vamos fazer ela dormir?

Ela olha pra minha cara e diz:

- Não é nenê, ela é preta, se vira sozinha!

Um pouco atônito com as palavras que a menina negra pequenininha havia me falado, peguei uma boneca não negra com formatos semelhantes àquela que Carolina havia me oferecido e perguntei:

$-\mathrm{O}$ nenê?

Carolina sorri e me diz:

- Sim, é nenê! Faz ela dormir.

Poucos segundos depois, ela viu a colega chegando e saiu correndo para abraçá-la, me deixando com este questionamento: as meninas negras pequenininhas não são nenês? O que representa ser uma menina negra? O que é ser uma nenê negra?

Esse momento da pesquisa me deixou alguns dias confuso; meu olhar e a minha interpretação a respeito do processo de construção das intersecções entre a racialização e as relações de gênero começaram a se reestruturar, a ganhar formas antes imperceptíveis para mim, homem branco. A fala de Carolina fazia ressoar em minha mente o discurso que Sojourner Truth, ex-escravizada negra, proferiu na Convenção dos Direitos das Mulheres, em Ohio, Estados Unidos, em 1851:

Aquele homem ali diz que é preciso ajudar as mulheres a subir numa carruagem, é preciso carregar elas quando atravessam um lamaçal e elas devem ocupar sempre os melhores lugares. Nunca ninguém me ajuda a subir numa carruagem, a passar por cima da lama ou me cede o melhor lugar! E não sou uma mulher? Olhem para mim! Olhem para meu braço! Eu capinei, eu plantei, juntei palha nos celeiros e homem nenhum conseguiu me superar! E não sou uma mulher? Eu consegui trabalhar e comer tanto quanto um homem - quando tinha o que comer - e também aguentei as chicotadas! E não sou uma mulher? Pari cinco filhos e a maioria deles foi vendida como escravos. Quando manifestei minha dor de mãe, ninguém, a não ser Jesus, me ouviu! E não sou uma mulher? (TRUTH, 1851 apud JABARDO, 2012, s/p).

Quando falamos em fragilidade feminina, de quais mulheres estamos falando? Como aponta Carneiro (2003), a cor negra de homens, mulheres e crianças no Brasil transmuta a epiderme corporal, assumindo um caráter cultural que referencia os processos de "integração" ou não desses sujeitos na sociedade, marcando diretamente as relações raciais, de gênero, de classe e de idade.

O processo de construção das relações de gênero dentro da chave da colonialidade se estabelece de modo diferente entre homens e mulheres brancos, mulheres negras e homens negros: "fêmeas colonizadas nunca foram compreendidas como em falta por não serem como-homens, tendo sido convertidas em viragos. Homens colonizados não eram compreendidos como em falta por não serem como-mulheres" (LUGONES, 2014, p. 937).

A colonialidade cria um lugar em que a humanidade não pertence a todos, transformando em coisas aqueles que não pertencem a seu grupo étnico, construindo assim experiências distintas entre os sujeitos que compõem a sociedade. Nesse contexto, ao mesmo tempo que a colonialidade desumaniza as pessoas negras legitima a construção da superioridade do branco, que representa "o humano". Por isso, é "preciso evitar o mecanismo das análises apressadas que reproduzem enfoques sem preocupação com a dialética dos processos" (WHITAKER, 2002, p. 09).

Nesse sentido, "a gente precisa refletir bastante para perceber as intersecções entre raça, classe e gênero, de forma a perceber que entre essas categorias existem relações que são mútuas e outras que são cruzadas" (DAVIS, 2011). Quando representamos as mulheres negras como "independentes", 
construímos um processo que as torna responsáveis por suas próprias condições, culpabilizando a vítima e reforçando os privilégios legitimados pela estrutura racial da sociedade ${ }^{10}$.

Como bem lembra Scott (1995), em seu artigo "Gênero: uma categoria útil de análise histórica", o gênero é um elemento constitutivo de relações sociais baseadas nas diferenças percebidas entre os sexos, mas é também uma forma primária de significar as relações de poder, relações estas que produzem efeitos na esfera do desejo, nos modos de vida.

As relações de gênero são resultado do contexto sociocultural que as produziu; "seus usos e significados nascem de uma disputa política e são os meios pelos quais as relações de poder - de dominação e de subordinação - são construídas" (SCOTT, 1995, p. 12-13). Ao trazermos as relações de gênero para o âmbito conceitual, procuramos evidenciar os processos de construção das desigualdades e a diferença entre homens e mulheres (SCOTT, 1995). O poder envolvido nessas relações não se trata de um elemento centrado, duro e único, mas é orgânico e micropolítico. Como afirma Foucault (1999, p. 374), "toda relação humana é, até certo ponto, uma relação de poder". Para compreender essa afirmação, é necessário pensar o poder independentemente dos valores morais e jurídicos que o recobre, ou seja, pensar o poder para além do bom ou do mau, do certo ou do errado.

Nesse sentido, quando as feministas negras apontam a necessidade de pensar as relações de gênero, raciais, de classe e idade de modo interseccionado não apenas afirmam a necessidade de trabalhar com a multiplicidade de diferenciações que marcam socioculturalmente determinados grupos, mas também apontam a relevância conjuntural de perceber suas interconexões, e como o social se torna corporificado (PISCITELLI, 1996; FAUSTO-STERLING, 2002). Para exemplificar o processo de intersecção, Butler (2003, p. 20) afirma que "o gênero estabelece interseções com modalidades raciais, classistas, étnicas, sexuais e regionais de identidades discursivamente constituídas", por isso "se tornou impossível separar a noção de 'gênero' das interseções políticas e culturais em que invariavelmente ela é produzida e mantida".

Rosemberg (1996) problematiza que a busca pela compreensão das intersecções entre raça, gênero, classe social e idade inúmeras vezes toma como pressuposto um modelo acumulativo entre marcadores, que espera uma associação linear entre eles e está aquém da possibilidade de entendimento da complexidade e das contradições que envolvem as dinâmicas de gênero, raça e classe. Essas categorias não são redutíveis umas às outras; "[...] a intersecção dessas relações pode levar a interrupções, descontinuidades, alterações ou incrementos do impacto original das dinâmicas de raça, classe ou gênero em dado contexto social ou institucional" (ROSEMBERG, 1996, p. 59).

Ao encontro dessa forma de percepção das relações interseccionais, Saffioti (2015, p. 83) aponta que,

efetivamente, o sujeito, constituído em gênero, classe e raça/etnia, não apresenta homogeneidade. Dependendo das condições históricas vivenciadas, uma destas faces estará proeminente, enquanto as demais, ainda que vivas, colocam-se à sombra da primeira. Em outras circunstâncias, será uma outra faceta a tornar-se dominante. Esta mobilidade do sujeito múltiplo acompanha a instabilidade dos processos sociais, sempre em ebulição.

Todavia, tanto o sexismo quanto o racismo são dinâmicas determinadas e construídas historicamente. São fenômenos que desempenham funções multiformes, totalmente benéficas para um grupo que, por meio delas, constrói e mantém um poder hegemônico em relação ao restante da sociedade (MOORE, 2012). O sexismo e o racismo, para Gonzalez (1983), seriam variações de um tema mais geral, que tem nas diferenças biológicas (reais ou imaginadas) o ponto de partida para o estabelecimento de ideologias de dominação e opressão. No Brasil, são invocados a partir do referencial de três figuras da nossa cultura: a mulata, a doméstica e a mãe preta.

Acerca dessas referências, podemos observar que as mulheres negras estão ligadas ao espaço público, seja pela exploração do trabalho ou da sexualidade, seja por uma idealização da maternagem,

${ }^{10}$ Processo semelhante pode ser observado em relação às mulheres indígenas (PINTO, 2010).

Educação em Revista|Belo Horizonte|v.36|e220090|2020 
diferentemente das brancas. Os homens, dentro do processo de reprodução da divisão sexual do trabalho, foram cúmplices, "tendo em vista que tentaram manter seu poder com relação ao capital, por meio da desvalorização e da disciplina das mulheres, das crianças e das populações colonizadas pela classe capitalista" (FEDERICI, 2017, p. 214).

"A mulher negra é o ser humano mais esmagado de todas as categorias de pessoas marginalizadas no mundo. E não se pode ignorar isso" (MOORE, 2012). Os processos de racialização tornam a construção da feminilidade negra de caráter público uma marca que é derivada historicamente das relações de exploração.

Como ressalta a filósofa feminista negra norte-americana Davis (2016), a respeito da realidade sociocultural dos Estados Unidos, os locais que as mulheres negras ocupam no espaço público inúmeras vezes reproduzem um padrão estabelecido nos períodos da escravidão. Como escravizadas, essas mulheres tinham aspectos da sua existência ofuscados pelo trabalho e pela necessidade de preservação da sua vida, sendo esquecidas enquanto humanas e passando a assumir somente o papel de trabalhadoras e objetos de um senhor. Por mais que essa análise se refira à realidade norte-americana, apresenta muitos pontos em comum com o contexto brasileiro, o qual também foi marcado por um processo de escravidão e construído sobre os pilares do racismo. No livro Mulheres, raça e classe, Davis (2016) também aponta que, à medida em que a ideologia da feminilidade se popularizava, as mulheres brancas passaram a ser vistas como habitantes de uma esfera totalmente separada do mundo do trabalho produtivo, mas entre as mulheres negras escravizadas "esse vocabulário não se fazia presente".

A raça equivale a um sistema de signos que identifica a posição do sujeito dentro do contexto social, assim como o sexo define um papel de gênero, sendo ambos construções sociais que não podem ser escolhidas individualmente (ALIETTI; PADOVAN, 2000). O que torna fundamental destacar nesse quadro, como aponta Mohanty (2012), é o desafio de perceber que as diferenças constroem conexões e cruzamentos que se distanciam das ideias universais, estabelecendo vivências singulares.

O sistema escravista, pautado na racialização, definia o povo negro como propriedade, como unidades de trabalho lucrativo, desprovido de humanidade, o que implicou diferentes consequências para seus modos de vida. A esse respeito, a feminista negra bell hooks ${ }^{11}$ (2010), no artigo "Vivendo de amor", apresenta que, em diferentes momentos históricos, a população negra foi proibida de expressar seus sentimentos.

Isso não deveria nos surpreender, já que nossos ancestrais testemunharam seus filhos sendo vendidos; seus amantes, companheiros, amigos, apanhando sem razão. Pessoas que viveram em extrema pobreza e foram obrigadas a se separar de suas famílias e comunidades não poderiam ter saído desse contexto entendendo essa coisa que a gente chama de amor. Elas sabiam, por experiência própria, que na condição de escravas seria difícil experimentar ou manter uma relação de amor.

Imagino que, após o término da escravidão, muitos negros estivessem ansiosos para experimentar relações de intimidade, compromisso e paixão, fora dos limites antes estabelecidos. Mas é também possível que muitos estivessem despreparados para praticar a arte de amar. Essa talvez seja a razão pela qual muitos negros estabeleceram relações familiares espelhadas na brutalidade que conheceram na época da escravidão. Seguindo o mesmo modelo hierárquico, criaram espaços domésticos em que conflitos de poder levavam os homens a espancarem as mulheres e os adultos a baterem nas crianças, para provar seu controle e sua dominação. Estavam assim se utilizando dos mesmos métodos brutais que os senhores usaram contra eles. Sabemos que sua vida não era fácil; com a abolição da escravatura, os negros não ficaram imediatamente livres para amar.

hooks (2010) referia-se a um contexto sociocultural diferenciado, o espaço afro-americanodo-norte; mesmo assim, suas formulações são interessantes para entendermos como as condições históricas podem influenciar a maneira pela qual a sociedade marcada pelo racismo constrói as relações amorosas e como são estabelecidas as relações de afeto entre as pessoas. A partir da recuperação da sua trajetória, hooks (2013, p. 86) conclui que o processo de se pensar e teorizar está fundamentalmente

\footnotetext{
${ }^{11}$ Gloria Jean Watkins, escritora e militante feminina. Adotou como pseudônimo o nome de sua avó (bell hooks) e prefere que seja escrito em minúsculo, para que a atenção seja concentrada em sua mensagem, ao invés de em si mesma. Para maiores informações, acessar : http://grafiasnegras.blogspot.com/2013/10/personalidades-negras-bell-hooks.html

Educação em Revista|Belo Horizonte|v.36|e220090|2020
} 
ligado à autorrecuperação e libertação coletiva, não existindo brechas entre a teoria e a prática em "um processo que, em última análise, é recíproco, onde uma capacita a outra”.

As construções sociais forjadas pelo processo de racialização transbordam os entraves das estruturas sociais de classe, passando a influenciar as diferentes instâncias das vidas das pessoas brancas e negras entre as construções das relações afetivas. A perversidade da racialização retira a humanidade dos sujeitos, limitando-os/as em suas vivências tanto afetivas quanto ancestrais, de modo a marcá-los/as como objetos.

Contudo, essa lógica de desumanização sempre foi colocada em xeque e redesenhada de diferentes modos pelas pessoas negras; como exemplo, Slenes (2011) coloca as alianças e os laços afetivos que os escravizados e as escravizadas estabeleciam no interior da senzala. Ao formarem tais laços, os/as escravizados/as aumentaram ainda mais sua vulnerabilidade, mas isso não quer dizer que esses mesmos laços não contribuíram para a construção de caminhos para a solidariedade. Um exemplo de laços afetivos de resistência são os quilombos, construídos ao longo de todo o período escravocrata do Brasil. Também podemos lembrar que as/os escravizadas/os, após terríveis jornadas de trabalho, entregavamse à dança e ao canto, expressando sua dimensão humana lúdica e contrapondo-se à lógica de que seus corpos eram máquinas; o mesmo corpo que era sacrificado, desumanizado, transcendia e brincava, sambava, jongava.

Nesse momento, retomamos a ideia de que o não afeto, bem como a dureza diante da vida dos negros e das negras, é uma construção de cunho cultural e social:

O Negro não existe, enquanto tal. É constantemente produzido. Produzir o Negro é produzir um vínculo social de submissão e um corpo de exploração, isto é, um corpo inteiramente exposto à vontade de um senhor, e do qual nos esforçamos para obter o máximo de rendimento. Mercê de trabalhar à corveia, o Negro é também nome de injúria, o símbolo do homem que enfrenta o chicote e o sofrimento num campo de batalha em que se opõem grupos e facções sociorracialmente segmentadas. (MBEMBE, 2014, p. 40)

Nesse sentido, retornando ao fragmento do diário de campo exposto anteriormente, podemos problematizar a frase da criança Carolina: "Não é nenê, ela é preta, se vira sozinha", a qual expõe todo o legado histórico que recai sobre a mulher negra e, consequentemente, reverbera nas inúmeras instâncias vivenciadas durante a infância pelas meninas negras pequenininhas. A fala lembra Guattari (1987, p. 53-54), quando afirma que "simplesmente trocou-se a roupa da velha crueldade da iniciação que consiste em extirpar da criança, o mais cedo possível, sua capacidade específica de expressão, e em adaptá-la o mais cedo possível aos valores, significações e comportamentos dominantes".

A menina negra pequenininha anuncia uma localização social para a qual as pessoas pretas foram historicamente designadas, apresentando uma intersecção de relações em que os sistemas de raça, classe social, gênero se estabelecem concomitantemente. Como destaca Collins (2000), conhecer uma mulher somente a partir da sua identidade de gênero, em uma sociedade sexista, é informação insuficiente para descrever sua experiência; é necessário também conhecer outros sistemas que a atravessam, como o processo de racialização e a estratificação de classe.

Brah (2006, p. 341) vai ao encontro dessa forma de percepção:

Nosso gênero é constituído e representado de maneira diferente segundo nossa localização dentro de relações globais de poder. Nossa inserção nessas relações globais de poder se realiza através de uma miríade de processos econômicos, políticos e ideológicos. Dentro dessas estruturas de relações sociais não existimos simplesmente como mulheres, mas como categorias diferenciadas, tais como "mulheres da classe trabalhadora", "mulheres camponesas" ou "mulheres imigrantes". Cada descrição está referida a uma condição social específica. Vidas reais são forjadas a partir de articulações complexas dessas dimensões. 
Essa noção do sujeito marcado pelo gênero como lugar de múltiplas diferenças é o resultado das críticas das feministas negras, que passam a conceber os sujeitos enquanto possuidores/as de identidades múltiplas, feitas de representações heterogêneas e heterônomas de gênero, raça, classe e idade.

Carolina, por meio de sua fala, possibilita também questionarmos a percepção de infância eurocêntrica e única, que em diferentes momentos não respalda as crianças negras pequenininhas, em especial as meninas negras, que "devem" "se virar sozinhas" desde muito pequenininhas. A infância é uma produção histórica e "não podemos hoje, na sociedade capitalista, pensá-la em abstrato, referindonos à criança independentemente de sua classe social" (FARIA, 2007, p. 61), de seu pertencimento étnico-racial, das relações de gênero.

Souza (2012), em sua Dissertação de Mestrado, intitulada Percepções de infância de crianças negras porprofessoras de Educação Infantil, afirma que as percepções das infâncias em nossa sociedade são pautadas, inúmeras vezes, em experiências do que é ser uma criança branca; segundo a pesquisadora, essas percepções são alicerçadas pelas estruturas de distorções e desigualdades que envolvem a população negra brasileira. Os meninos negros e as meninas negras estão em inúmeros momentos impedidas/os do direito ao cuidado, do afeto, do acesso aos bens econômicos, simbólicos e culturais.

O que está em jogo não é somente o afeto compreendido em uma chave estritamente burguesa, que constrói uma percepção de infância que, ao mesmo tempo, possibilita a atenção para as crianças e estabelece limites para se viver e pensar além do conceito daquilo já posto anteriormente à construção do ato de afeto, que muitas vezes sufoca ou marca as vidas de meninas e meninos com projetos pré-estabelecidos em padrões e caminhos de vidas normativos. Como aponta Oliveira (2004), pode parecer negativo que as crianças negras não recebam carinho e acolhimento por parte das profissionais da creche, mas não é, pois o âmbito relacional também é um aparelho de captura e controle; eis a positividade de se estar fora dessa prática. Assim, as crianças negras estariam excluídas de serem tratadas como bibelôs, bonecas, e livres desse afeto inibidor, fraternal e familiar que asfixia e aprisiona. Entretanto, como destaca Nunes (2016, p. 398), é necessário ter um pouco de atenção a essa afirmação, pois “também não é possível ter certeza que tornar-se outra coisa diferencie-se substancialmente daquilo que uma criança negra já experimenta em seu cotidiano, marcadas que são por serem coisas, coisas estas ligadas à ausência e ao desvio".

O processo de racialização tem como um dos seus pilares a ausência: constrói o apagamento histórico da ancestralidade de diferentes povos - um controle político da memória (CURCIO; MELLINO, 2012) -, bem com a não legitimação dos afetos e de laços que confeririam ao sujeito negro o direito a relações básicas de carinho, amorosidade, sororidade, fraternidade. Afinal, as pessoas negras, dentro da chave do processo histórico de racialização, são somente "coisas", não possuindo acesso a elementos sociais que as transformem em humanos. Não advogamos um afeto que sufoca, castra, mas apontamos, a partir da fala da menina negra pequenininha Carolina, que as crianças negras podem aprender e "experienciar" desde muito pequenas que o afeto e o cuidado fazem parte da infância vivenciada somente por crianças brancas.

Poder-se-ia aqui empregar, analogamente, a expressão conceitual "fazer viver e deixar morrer", cunhada por Foucault (2002) ${ }^{12}$.

Com base nos padrões normalizadores e em nome dos que devem viver, estipula-se quem deve morrer - "a morte do outro, da raça ruim é o que vai deixar a vida em geral mais sadia" (Foucault, 2002:305). Assim, o racismo do século XIX já não pode ser encarado meramente como fruto do ódio entre as raças, mas como uma doutrina

\footnotetext{
${ }^{12}$ Como aponta Rosa (2007, p.02), tratava-se da assunção da vida pelo poder, da biopolítica, como denominou Foucault (2002): “O poder disciplinar, que já em fins do século XVII centrava-se no corpo individual (organizando, esquadrinhando, vigiando), possibilitou à biopolítica implantar-se em uma outra escala. Tomando a vida como elemento político por excelência, a biopolítica perpassou o antigo poder soberano. Com os investimentos de poder centrados no homem-espécie, a vida passou a ser administrada e regrada pelo Estado. Em nome da proteção das condições de vida da população, preserva-se a vida de uns, enquanto autoriza-se a morte de outros tantos. Se o poder soberano já expunha a vida humana individual à morte, ainda que de maneira limitada, o biopoder expõe a vida de populações e grupos inteiros". 
política estatal a justificar a atuação violenta dos Estados modernos. No limiar da modernidade biológica - diz Foucault (2002: 134) - a espécie ingressou no jogo das estratégias políticas. Isso não significa que a vida tenha sido totalmente integrada às técnicas que a gerenciam, "ela lhes escapa continuamente". (ROSA, 2007, p. 3)

Nesse contexto, outorga-se a alguns o direito de "experienciar" o mundo como criança e, a outros, reserva-se a morte resultante dos efeitos nefastos do racismo: uma morte social, dilacerada para além do próprio sentimento de luto.

Os brancos, nesse contexto, desfrutam de grandes privilégios, como se a ordem social vigente estivesse posta para garantir somente os interesses preestabelecidos por esse grupo, fundando abismos sociais pautados em diferenças fenotípicas que cunham processos de exclusão e criando laços ideológicos que constroem e advogam a existência, entre negros e brancos, de uma distância não só social e cultural, mas também biológica (FERNANDES, 1972).

\section{EDUCAÇÃO INFANTIL E PENSAMENTO INTERSECIONAL}

O cuidar e o educar são elementos indissociáveis na Educação Infantil, e a afetividade construída nas trocas das fraldas, no acolhimento da chegada à creche, na hora da alimentação das crianças e nas trocas de olhares torna-se racista ao não garantir a construção das mesmas trocas afetivas para todas as crianças pequenininhas. Destaco que essa percepção a respeito dos bebês enquanto "sujeitos não ativos" e a potencialidade para o novo têm como referência a percepção de infância eurocentrada branca. $O$ interessante é que esse mesmo referencial constrói marcas coloniais que distinguem as crianças negras pequenininhas antes mesmo do seu nascimento; os/as bebês negros/as, em nossa sociedade racista, são símbolo da reprodução da pobreza, da criminalidade, carregando consigo o legado racial instituído nas tessituras da colonialidade.

A questão racial suprime a própria condição infantil, interditando as possibilidades que esta pode proporcionar na "experienciação" do mundo pelas crianças negras, destinando-as a locus hierárquicos na sociedade. "A questão crucial é que esta representação da criança [negra] transforma-se em realidade à medida que a própria criança passa a se definir tomando como referência o que o adulto e a sociedade esperam dela" (BERNARDES, 1989, p. 311).

O corpo negro do/a bebê é marcado pela desigualdade desde o primeiro choro. Afinal, ele/ela não necessita de tanto dengo, não representa o modelo de beleza, e uma pequena mordida que realiza em um/a colega pode levá-lo/la ao estigma de um/a futuro/a criminoso/a. Desde que está no útero de sua mãe, já se ouve: "Espero que ele seja mais clarinho! Não tenha cabelo ruim, ou nariz largo". "As crianças negras se constroem pessoas e cidadãs em situações de conflito, de reconhecimento e de desqualificação do seu pertencimento étnico-racial, da sua negritude” (SILVA, 2015, p. 181).

Ao encontro do questionamento das estruturas racistas do afeto, Martins e Mello (2010) narram uma crônica do cotidiano da educação intitulada "Dor de mordida tem cor?", na qual relatam que inúmeras vezes não damos a devida atenção a mordidas nas crianças negras pequenininhas, afinal não deixam marcas na pele. Para as autoras, as mordidas são acontecimentos da infância, mas o modo com que tratamos cada uma delas é expressão de como concebemos as relações sociais.

As percepções do que é ser uma criança negra pequenininha e os modos como os meninos negros pequenininhos e as meninas negras pequenininhas vão se estabelecendo no mundo são diretamente marcadas pelo contexto que vivenciam. Para pensarmos um pouco mais a respeito dessa questão, trago outro fragmento do diário de campo, ressaltando que as identidades, sejam étnicas-raciais, sejam de sexo-gênero ou de idade, são construídas a partir das nossas múltiplas relações para com o mundo.

Em uma manhã de segunda-feira, no ônibus que pegava para chegar até a creche, ouvi uma conversa entre duas mulheres negras trabalhadoras, mães de crianças pequeninhas que frequentavam a creche, as quais levavam seus filhos para a instituição pesquisada antes de ir para seus trabalhos, sentadas à frente do meu banco. A conversa me trouxe novas questões: 
- Sabe, tem gente que fala que não se pode ensinar os meninos a mexer na cozinha, mas eu ensinei meus filhos desde pequenos a cozinharem, senão eles morriam de fome! Eu passo o dia todo fora, eles têm que ir à escola, têm que comer; se não ensino, quem iria fazer pra eles? Crio meus filhos sozinha!

- É, você tem razão, eu também boto meus filhos a ajudarem, mas olha, lá em casa quem cozinha bem mesmo é o meu marido; ele bebe a pinga dele, mas faz um macarrão delicioso! (Fragmento do diário de campo, março de 2016).

Homens na cozinha? Ensinar os filhos desde pequenos a cozinhar? Isso me parece muito distinto dos ideais prescritos de masculinidade; talvez não corresponda a um ideal de homem provedor que espera sua esposa ou mãe trazer seu alimento e depois servi-lo em uma relação senhorial-patriarcal. Nesse processo, pode haver momentos em que o machismo esteja colocado à frente, mas o que viso a destacar é como a experiência das relações de gênero é marcada pela estratificação de classe e pela racialização.

Muitas mães das crianças que participaram da pesquisa de Gobbi (1997) para sua Dissertação de Mestrado, Lápis vermelho é de mulherzinha? Desenho infantil, relaçoes de gênero e educação infantil, afirmaram ensinar tarefas domésticas para os filhosm a fim de que pudessem desempenhar tarefas quando estivessem sozinhos ou com suas esposas. Para a autora, essas mudanças apresentadas e carregadas pelas mulheres mães de meninos fazem refletir a respeito da necessidade de se relacionar etnia, classe social, raça e gênero para a compreensão das diferentes infâncias.

Há uma diferenciação quanto à classe social que cozinha, pois verificamos, em grandes restaurantes, considerados os que servem os melhores pratos, homens brancos coordenando as atividades da cozinha e sendo os melhores chefes. O ato de cozinhar ganha dimensões diferenciadas conforme a classe social em que está inserido, bem como é afetado por questões raciais e de gênero, e estabelecem-se distintos status sociais para essa atividade. Por exemplo, um homem branco de classe média, ao tornar-se um chef, ganha status de masculinidade, por representar diretamente o gestor da cozinha, aquele que dita ordens e detém todos os saberes relativos aos pratos que serão elaborados.

O que pretendemos argumentar é que na história do capitalismo o domínio de classes apareceu desde o início entrelaçado com o discurso de raça. Em suma: a noção moderna de raça, bem como as diferentes formas históricas de racismo a que ela deu origem, representa um dispositivo de comando constitutivo de todas as formações capitalistas modernas. (CURCIO; MELLINO, 2012, p. 08, tradução nossa)

A classificação racial foi um dos elementos principais para a hierarquização social, como mostra Santos (2006, p. 103): a relação de dominação e criação de privilégios é consequência e não causa da hierarquização, e pode ser considerada como uma obrigação de quem é classificado como superior, como o "fardo do homem branco" em suas missões civilizatórias. As pessoas negras, em uma sociedade construída por estruturas escravocratas e racialmente pensada para o benefício da população branca, não possuem o mesmo acesso a postos de trabalho, escolaridade etc.

A cor é um critério objetivo de estratificação. E mais, remete o indivíduo a uma raça, a uma classe. É, portanto, símbolo de uma classe (ALMEIDA, 1976). Na lógica hierárquica da racialização, a cor foi selecionada como marca racial que serviria para identificar socialmente os sujeitos e passou a ser "um símbolo da posição social, um ponto de referência imediatamente visível e inelutável, através do qual se poderia presumir a situação de indivíduos isolados, como socius e como pessoa" (BASTIDE; FERNANDES, 2008, p. 95).

Como destaca Akotirene (2018, p. 17),

enquanto as mulheres brancas têm medo de que seus filhos possam crescer e serem cooptados pelo patriarcado, as mulheres negras temem enterrar seus filhos vitimados pelas necropolíticas, que militar e confessionalmente matam e deixam morrer, contrariando o discurso cristão elitista-branco de valorização da vida e contra o aborto - que é um direito reprodutivo. Não havemos de escapar desta encruzilhada teórica. 
Ao encontro desse pensamento, quando pensamos no imaginário do homem negro que exerce a atividade de cozinheiro, corremos o risco de recair na expressão histórica de feminilidade negra, prescrita pelo racismo, que liga as negras às figuras de cozinheiras. Essa atividade é considerada um trabalho mecânico e braçal, retirado o seu papel intelectual, passando a ser associada à passividade, obediência e submissão femininas, características também esperadas dos homens negros. A colonização europeia, desde o início, construiu processos que racializam e sexualizam as relações de trabalho, isto é, desde os primeiros momentos de gestação do capitalismo e antes do aparecimento de classe no sentido marxista moderno do termo e das transformações neoliberais, ocorreu o entrelaçamento das relações sociais e estruturais e contradições entre apropriação coletiva e individual, bem como entre apropriação e exploração. Produziu-se uma dinâmica de interligação entre as relações sociais de sexo, de "raça" e de classe (FALQUET, 2017).

As mulheres negras, quando ensinam seus filhos a cozinhar, rompem as fronteiras do racismo, da estratificação de classe e do sexismo, apontando que essa atividade não é exercida somente por elas e que seus filhos possuem todo o potencial de organização e gerenciamento de uma cozinha.

Outro momento em que pude observar essas diferenças foi a entrada dos meninos pequenininhos e meninas pequenininhas na creche. $\mathrm{Na}$ abertura do portão da instituição, verifiquei que havia um número grande de homens negros que levavam as crianças para as suas turmas, algo que me deixou inquieto. Após alguns dias observando as cenas que se repetiam, perguntei ao vigilante se era comum os pais, avôs e irmãos trazerem as crianças para a creche, pois eu imaginava que mulheres desempenhariam em maior número essa função. Sem hesitar, o vigilante me disse: "as mulheres entram muito cedo no trabalho; como a maioria dos homens faz 'bico', eles que trazem as crianças; à tarde, as mães já saíram do serviço e vêm buscar" (informação verbal ${ }^{13}$ ).

Em A integração do negro na sociedade de classes, Fernandes (2008) contribui para refletir a respeito desse fenômeno, expondo de modo dramático como a inserção do homem negro no mercado de trabalho sofreu grandes entraves com o racismo. O autor aponta que as mulheres negras, inúmeras vezes, foram aceitas para continuar nos trabalhos domésticos, fosse pelo não aceite de mulheres brancas do exercício de tais funções, fosse pela falta de oportunidades no mercado de trabalho, sobrando-lhes os cargos com baixa remuneração e de menos prestígio. Enquanto isso, aos homens negros não foram conferidas outras possibilidades além de trabalhos sem vínculo empregatício, sem registro na carteira de trabalho ou documentação equivalente, sendo eles desprovidos de benefícios, como férias. Sem trabalho digno e remuneração adequada, em sua maioria o homem negro foi colocado em um estado de anomia, o que por sua vez dificultou o seu acesso aos mecanismos de ascensão, como a formação escolar.

Esse quadro ainda está presente em nossa sociedade, "construindo destinos" sociais aos homens negros/meninos negros que limitam, em grande parte, a sua inserção na sociedade de classe. Esse processo não se restringe ao mercado de trabalho e constrói caminhos racializados nas vivências relacionadas às relações de gênero, sexualidade e experiências no mundo. Em entrevistas concedidas pelas docentes da creche pesquisada ${ }^{14}$, pude observar que o imaginário racializado do que constitui a masculinidade negra estava presente no interior da creche:

"Eu acho que os meninos negros são mais agressivos, eles batem... aí de novo penso na questão social deles, do dinheiro, porque a gente sabe que existe violência doméstica, e nas classes mais baixas isso é mais explícito... você vivencia isso e retrata depois" (informação verbal , Harbuu, docente negra).

[...] os meninos negros são mais repreendidos, eles são mais... tem um pouco dessa concepção, assim, tem que segurar, porque isso... vai dar o quê? Aliás, eu já ouvi isso, né? Eu estou reproduzindo uma fala de uma educadora. Se eu não seguro, vai virar o quê? Bandido, marginal, violento. Então, ali a questão da cor da pele, da negritude, da afrodescendência, a possibilidade de virar marginal, eu já prefiro pensar que vai virar

\footnotetext{
${ }^{13}$ Fragmentos do caderno de campo de agosto de 2016.

${ }^{14}$ Entrevistas concedidas em 2016.
} 
um presidente da República, mas tem gente infelizmente que segura mais... (informação verbal12, Adeola, docente negra)

O estereótipo da malandragem, nas percepções a respeito dos meninos negros pequenininhos, não está recheado do glamour cantado em muitos sambas nacionais. Ele carrega o fardo cultural de um passado histórico pautado na lógica da colonialidade, marcado pelos princípios de civilidade impostos pela branquitude e pela desigualdade de classe presentes na sociedade capitalista. "O preto é um brinquedo nas mãos dos brancos" (FANON, 2008, p. 126). O imaginário que recai nos meninos negros pequenininhos ressoa as mais perversas estruturas do racismo ${ }^{15}$.

Dentre as características associadas ao estereótipo está a agressividade, que, como aponta Kimmell (2000), é valorizada e estimulada entre os meninos. Desde muito cedo é ensinado aos meninos que a violência não só é uma forma aceitável de resolução de conflitos, mas também uma prática digna de admiração. Entretanto, na fala das docentes, a agressividade não é associada a algo positivo da masculinidade negra, carregando em si a percepção do negro revoltado, violento, cruel, que pode ser associada à imagem de escravo algoz (BROOKSHAW, 1983) ou do "escravo demônio" (PROENÇA FILHO, 2004), que se revoltava contra as condições da escravidão, promovendo tumultos contra as regras e imposições coloniais escravocratas.

Os meninos negros pequenininhos são repreendidos com maior frequência, mas não somente porque se procura construir um "bom comportamento" diante dos combinados e das normas pré-definidas entre os/as membros/as da turma. É também pelo resgate de um passado colonial em que havia a necessidade fundamental de reprimir com violência o homem negro, para que ele não ousasse transpor as fronteiras da hierarquização escravocrata, expondo o medo latente de transgressões da população negra ao regime da colonialidade.

O reconhecimento de que a raça, a classe social e a sexualidade diferenciam as experiências dos meninos/homens e das meninas/mulheres rompe com a noção de categorias homogêneas de homem/menino e menina/mulher, e com suposições universalistas que servem para manter um projeto de sociedade legitimado pela lógica colonial eurocentrada (BRAH; PHOENIX, 2014). No entanto, como aponta Rosemberg (1996, p. 59),

[...] a alternativa de compreensão simultânea das hierarquias de gênero, raça e classe tem se baseado, muitas vezes, em modelo cumulativo, esperando-se uma associação (ou adição) das diferentes formas de subordinação. Nesse sentido, usam-se, por exemplo, expressões do tipo "a tripla discriminação da mulher negra". Este modelo associativo não dá conta, porém, da complexidade e das contradições observadas nas instituições educacionais onde a dinâmica de gênero, raça e classe não são redutíveis umas às outras, evidenciando, ao contrário, um momento não sincrônico.

Para a compressão das relações de gênero, é necessário conhecer a historicidade e as culturas que as legitimam, tornando visíveis as desigualdades, as hierarquias e a dinâmica social do método de representação do binarismo masculino e feminino e do legado colonialista do patriarcado, de modo a compreender as relações de poder que estabelecem a decodificação de elementos corpóreos em signos culturais. Essa forma de percepção permite que se "desessencialize" o gênero, já que este não se torna um ponto de partida dado, mas um pressuposto ou construção que se pode formalizar de forma não arbitrária por meio de experiências, práticas e discursos. Afinal, "o gênero é uma interpretação da nossa

\footnotetext{
15 Problematizamos também que a violência doméstica não ocorre apenas em classes socialmente mais desfavorecidas e em países em desenvolvimento como o Brasil, mas em diferentes classes e culturas. Segundo a Organização das Nações Unidas (ONU, 1995), a violência doméstica é a principal causa de lesões em mulheres entre 15 e 44 anos no mundo, podendo ser compreendida como uma violência de gênero (PIOVESAN, 2007).

O conceito de violência de gênero deve ser entendido como uma relação de poder de dominação do homem e de submissão da mulher. Essa violência é resultado dos papéis impostos a mulheres e homens no processo de socialização. Ou seja, não é a natureza a responsável pelos padrões e limites sociais que determinam comportamentos agressivos aos homens, e dóceis e submissos às mulheres (TELES, 2007).
} 
história dentro de uma constelação discursiva específica - uma história na qual somos sujeitos da construção social e estamos a ela sujeitados" (ALCOFF, 1988, p. 431).

O exercício de pensar as relações de modo interseccional, segundo McClintock (2010), possibilita uma ruptura no pensamento moderno, produzindo ideias teóricas pós-coloniais: raça, gênero e classe não são campos distintos e isolados da experiência. O gênero não está somente ligado aos atributos culturais construídos a partir de um "sexo biológico", mas também é uma questão de classe, de pilhagem colonial. Raça não é somente a cor da pele, mas também uma questão de divisão social das forças de trabalho incubada pelo gênero. Esses domínios não são redutíveis ou idênticos entre si; existem em relação íntima, recíproca e contraditória. Assim, podemos compreender esse processo a partir da ótica de consubstancialidade, cuja "geometria é variável, podendo incluir, além das relações sociais de gênero, de classe e de raça, outras relações sociais, como a de sexualidade, de idade, de religião" (HIRATA, 2014, p. 66).

Um exemplo é outro fragmento da entrevista realizada com Harbuu, docente negra, que problematiza como os atributos de gênero influenciam diretamente a construção da negritude, bem como atravessam o reconhecimento social do que é uma pessoa negra, ditando categorias racializadas especificamente para meninos/homens e meninas/mulheres:

Uma menina negra você alisa o cabelo [...] você consegue disfarçar sua negritude, entende? Porque, para a sociedade, para ser negra a pessoa tem que estar com aquela roupa colorida, com lenço na cabeça, com o cabelo crespo, aí sim ela é negra? Nesse sentido, a menina, se você quiser, você disfarça, ela vira a morena, a mulata. Você alisa o cabelo dela, você faz progressiva, você põe roupinha sem cor... E aí você disfarça. Ela não é negra, ela é parda, ela é morena, mulata. Já o menino, fisicamente é mais complicado disfarçar a negritude. (informação verbal , Harbuu - docente negra ${ }^{16}$ )

Harbuu, por meio de sua fala, nos remete às ideias de Gomes (2002): o corpo não é um simples componente biológico; é um campo de significação no qual pairam as sensações, as pressões e os julgamentos. As maneiras pelas quais cada sociedade impõe ao indivíduo um uso determinado de seu corpo expressam as relações sociais estabelecidas, como destaca Mauss (1950, p. 34): “o corpo é o primeiro e o mais natural instrumento do homem. $\mathrm{O}$ mais exatamente, sem falar de instrumento, o primeiro e mais natural objeto técnico, e ao mesmo tempo meio técnico do homem é seu corpo".

O corpo negro, no contexto brasileiro, ganha adjetivos pautados nos atributos da teoria da mestiçagem, amplamente defendida por Freyre (2005), em Casa-Grande \& Senzala, cuja primeira edição data de 1933. O livro oferece um novo modelo para a sociedade multirracial brasileira, partilhando da análise de que a mestiçagem é o resultado de uma boa escravidão existente no Brasil, retomando argumentos do início do século XX para fundamentar sua análise. O autor toma uma posição teórica e não aponta as implicações de um sistema como esse, tanto no âmbito singular do sujeito escravizado, como no contexto macroestrutural das relações hierárquicas da sociedade capitalista.

O pano de fundo que marca esse movimento é a ideologia do branqueamento, associada diretamente às relações de poder patrimonialistas que têm marcado o contexto social do nosso país. $\mathrm{O}$ ideário do branqueamento expressa uma recusa ou resistência histórica não apenas à especialização dos conceitos de inclusão e exclusão, mas também à burocratização das relações sociais como um todo (HOFBAUER, 2006, p. 409).

Em uma sociedade marcada historicamente por uma hierarquia racial, como a brasileira, os descendentes de "mestiços" não são brancos. Esse fato por si só nos convida à construção de um movimento constante em busca do branqueamento estético, cultural, social, criando o imaginário de que os negros e as negras podem esperar que seu/suas filhos/as sejam capazes de furar as barreiras decorrentes do seu pertencimento racial, caso tenham pele com tom mais claro ou cabelos lisos (OLIVEIRA, 1974).

\footnotetext{
${ }^{16}$ Entrevista concedida em 2016.
} 
Entretanto, essa forma de segregação racista não "caiu do céu"; possui uma historicidade que

[...] nasce quando se faz intervir características biológicas como justificativa de tal ou tal comportamento. É justamente o estabelecimento da relação intrínseca entre caracteres biológicos e qualidades morais, psicológicas, intelectuais e culturais que desemboca na hierarquização das chamadas raças em superiores e inferiores. (MUNANGA, 2004, p. 25)

Trata-se de ranço colonial que se articula a partir do legado patriarcal de modelo senhorial, construído durante o período escravocrata brasileiro, o qual legitimou o estabelecimento de relações de dominação cultural eurocêntrica ao longo dos séculos de escravidão, de modo que a expropriação colonial racializada e racista em que vivemos (WERNECK, 2010) marca diferentemente homens e mulheres com base no pertencimento racial.

O racismo é um fenômeno ocidental e moderno (TAGUIEFF, 1999), que ressoa cotidianamente em nossa sociedade e é constatada corriqueiramente nas observações construídas a respeito dos meninos pequenininhos negros.

A partir dessa perspectiva, o pensamento interseccional constitui-se em ferramenta teóricometodológica fundamental para compreender e desvelar os processos de interação entre relações de poder e categorias como classe, gênero e raça em contextos individuais, práticas coletivas e arranjos culturais/institucionais. As experiências que marcam as histórias de meninas brancas pequenininhas e meninos brancos pequenininhos, e meninas negras pequenininhas e meninos negros pequenininhos são distintas e colocam-nos/nas em lugares sociais também diferenciados na estrutura hierárquica do sexismo e de classe.

\section{REFERÊNCIAS}

ABRAMOWICZ, Anete. A menina repetente. 4. ed. Campinas: Papirus, 2001.

ABRAMOWICZ, Anete; CRUZ, Ana Juvenal; RODRIGUES, Tatiane Consentino. A educação infantil e processos de racialização. In: PEREIRA, Reginaldo Santos; PIRES, Ennia Débora Passos Braga. Infância, pesquisa e Educação: olhares plurais. Curitiba: CVT, 2017. p. 15-30.

AKOTIRENE, Carla. O que é interseccionalidade? Belo Horizonte: Letramento/Justificando, 2018.

ALCOFF, Linda. Cultural Feminism versus Poststructuralism: The Identity Crisis in Feminist Theory. Signs, v. 3, n. 13, 1988, p. 405-436

ALIETTI, Alfredo; PADOVAN, Dario. Sociologia del razzismo. Caocci Editore: Roma, 2000.

ALMEIDA, Maria Suely Kofes de. Entre nós, os pobres, eles os negros. 1976. Dissertação (Mestrado em Antropologia Social) - Universidade Estadual de Campinas, Campinas, 1976.

ARAUjO, Tereza C. N. A classificação de “cor" nas pesquisas do IBGE: notas para uma discussão. Cadernos de Pesquisa, n.63, p.14-16, nov.1987.

BASTIDE, Roger; FERNANDES, Florestan. Brancos e negros em São Paulo. São Paulo: Globo, 2008.

BELOTTI, Elena. Educar Para a Submissão: o Descondicionamento da Mulher. Petrópolis: Vozes, 1987. 
BERNARDES, Nara M. G. Crianças oprimidas: autonomia e submissão. 1989. 348 f. Tese (Doutorado em Educação) - Universidade Federal do Rio Grande do Sul, Porto Alegre, 1989.

BRAH, Avar. Diferença, diversidade, diferenciação. Cadernos Pagu, Campinas, n. 26, p. 329-376, 2006.

BRAH, Avtar; PHOENIX, Ann. Ain't I A Woman? Revisiting Intersectionality, Journal of International Women's Studies, v. 5, n. 3, p. 75-86, 2014.

BROOKSHAW, David. Raça e cor na literatura brasileira. Porto Alegre: Mercado Aberto, 1983.

BUTLER, Judith. Problemas de gênero: Feminismo e subversão da identidade. Rio de Janeiro: Civilização brasileira, 2003.

CARNEIRO, Sueli. Enegrecer o feminismo: a situação da mulher negra na América Latina a partir de uma perspectiva de gênero. In: ASHOKA EMPREENDIMENTOS SOCIAIS; TAKANO CIDADANIA (Orgs.). Racismos contemporaneos. Rio de Janeiro: Takano Editora, 2003. p. 49-58.

COHN, Clarice. Antropologia da criança. Rio de Janeiro: Zahar, 2005.

COLLINS, Patricia Hill. Black feminist thought. knowledge, consciousness, and the politics of empowerment. New York: Routledge, 2000.

CORRÊAA, Lajara Janaina Lopes. Um estudo sobre as relações étnicorraciais na perspectiva das crianças pequenas. 2017. 179 f. Tese (Doutorado em Educação) - Universidade Federal de São Carlos, São Carlos, 2017.

CORSARO, William. Sociologia da infância. 2. ed. Porto Alegre: Artmed, 2011.

COUTINHO, Angela Scalabrin. Os novos estudos sociais da infância e a pesquisa com crianças bem pequenas. Educativa, Goiânia, v. 19, n. 1, p. 762-773, set./dez. 2016.

CRENSHAW, Kimberlé. Documento para o encontro de especialistas em aspectos da discriminação racial relativos ao gênero. Rev. Estudos Feministas. v. 10, n. 1, p. 171-188, 2002. Disponível em: <http://www.scielo.br/scielo.php?pid=S0104-026X2002000100011\&script=sci_abstract\&tlng=pt $>$. Acesso em: 1 jan. 2019.

CURCIO, Anna; MELLINO, Miguel. La Razza al Lavoro: Rileggere il razzismo, ripensare l'antirazzismo in Itália. In: CURCIO, Anna; MELLINO, Miguel (Orgs.). La razza al lavoro. Roma: Manifesto Libri, 2012. p. $07-36$.

DAVIS, Angela. Mulheres, raça e classe. São Paulo: Boitempo, 2016.

DAVIS, Angela. As mulheres negras na construção de uma nova utopia. Geledés, 12 jul. 2011. Disponível em: $\quad<$ http://www.geledes.org.br/as-mulheres-negras-na-construcao-de-uma-nova-utopia-angeladavis>. Acesso em: 13 mar. 2017.

DAVIS, Kathy. Intersectionality as buzzword, a sociology of science perspective on what makes a feminist theory successful. Feminist Theory, v. 9, n. 1, p. 67-85, 2008.

FALQUET, Jules. La combinatoria straight. Raza, clase, sexo y economía política: análisis feministas materialistas y decoloniales. Descentrada, v. 1, n. 1, p. e005, 2017.

FANON, Frantz. Pele negra, máscaras brancas. Salvador: EDUFBA, 2008. 
FARIA, Ana Lúcia Goulart de. Educação pré-escolar e cultura: para uma pedagogia da educação infantil. Campinas: Cortez; Editora Unicamp, 2007.

FAUSTO-STERLING, Anne. Dualismos em duelo. Cadernos Pagu, v. 17/18, p. 9-79, 2001/2002.

FEDERICI, Silvia. Calibã e a bruxa: Mulheres, corpo e acumulação primitiva. São Paulo: Editora Elefante, 2017.

FERNANDES, Florestan. Sociedade de classes e subdesenvolvimento. Rio de Janeiro: Zahar, 1972.

FERNANDES, Florestan. As trocinhas do Bom Retiro: Folclore e mudança social na cidade de São Paulo. São Paulo: Martins Fontes, 2004.

FERNANDES, Florestan. A integração do negro na sociedade de classe. 2. ed. São Paulo: Global, 2008.

FOUCAULT, Michel. História da sexualidade 1: a vontade de saber. Rio de Janeiro: Graal, 1999.

FOUCAULT, Michel. Em defesa da sociedade. Curso no Collège de France (1975-1976). São Paulo: Martins Fontes, 2002.

FREYRE, Gilberto. Casa-Grande \& Senzala. São Paulo: Global Editora, 2005.

GOBBI, Márcia Aparecida. Lápis vermelho é de mulherzinha? Desenho infantil, relações de gênero e educação infantil. 1997. Dissertação (Mestrado em Educação) - Universidade Estadual de Campinas, Campinas, 1997.

GOMES, Nilma L. Corpo e cabelo como ícones de construção da beleza e da identidade negra nos salões étnicos de Belo Horizonte. 2002. Tese (Doutorado em Antropologia Social) - Universidade de São Paulo, São Paulo, 2002.

GOMES, Nilma L. Informação Verbal: Palestra proferida no $13^{\circ}$ Congresso Mundos de Mulheres (MM) \& Seminário Internacional Fazendo Gênero 11 (FG), 01 de agosto de 2017.

GONZALEZ, Lélia. Racismo e sexismo na cultura brasileira. In: SILVA, Luiz Antonio Machado et al. Movimentos sociais urbanos, minorias étnicas e outros estudos. Ciências Sociais Hoje, v. 2. Brasília: ANPOCS, 1983. p. 223-244.

GUATTARI, Felix. As creches e a iniciação. In: GUATTARI, Felix. Revolução molecular: pulsação política do desejo. São Paulo: Brasiliense, 1987. p. 50-55.

GUIMARÃES, Alfredo S. A. Raça, cor, cor da pele e etnia. Cadernos de Campo, v. 20, p. 265-272, 2011.

HALL, Stuart. New Ethnicities. In: DONALD, James; RATTANSI, Ali (Orgs.). Race, culturs and difference. London: Sage, 1992. p. 252-259.

HIRATA, Helena. Gênero, classe e raça Interseccionalidade e consubstancialidade das relações sociais. Tempo Social, v. 26, n. 1, p. 61-73, jun. 2014.

HIRSCHFELD, Lawrence A. Por que os antropólogos não gostam de crianças? Latitude, v. 10, n. 2, p. 171-216, 2016. 
hooks, bell. Vivendo de amor. Geledés, 09 mar. 2010. Disponível em: $<$ http://arquivo.geledes.org.br/areas-de-atuacao/questoes-de-genero/180-artigos-de-genero/4799vivendo-de-amor>. Acesso em: 22 dez. 2015.

hooks, bell. Ensinando a transgredir a educação como prática da liberdade. São Paulo: WMF Martins Fontes, 2013.

HOFBAUER, Andreas. Uma história de branqueamento ou o negro em questão. São Paulo: Editora da Unesp, 2006.

IANNICIELLO, Celeste. Spazi e confini, transiti e posizionamenti. In: IANNICIELLO, Celeste; QUADRARO, Michaela. Memorie transculturali: Estetica contemporanea e critica postcoloniale. Napoli: Università degli studi di Napoli “L’Orientale”, 2015, p. 63- 88.

JABARDO, Mercedes. Feminismos Negros: una antología. Madrid: Traficantes de Sueños, 2012.

KIMMELL, Michael. What about the boys: what the current debates tell us and don't tell us about boys in school, Michigan: MPublishing; Biblioteca da Universidade de Michigan; Ann Arbor, v. 14. 2000.

LUGONES, María. Rumo a um feminismo descolonial. Revista Estudos Feministas, Florianópolis, v. 22, n. 3, p. 935-952, set. 2014. ISSN 1806-9584. Disponível em: <https://periodicos.ufsc.br/index.php/ref/article/view/36755>. Acesso em: 23 out. 2018.

MARTINS, Maria aparecida dos; MELLO, Ana Maria. Dor de mordida tem cor? In: MELLO, Ana Maria et al. (Orgs.). O dia a dia das creches e pré-escolas: Crônicas brasileiras. Porto Alegre: ArtMed, 2010. p. 54-56.

MAUSS, Marcel. Sociologie et Anthropologie. Paris: PUF, 1950.

MBEMBE, Achille. Crítica da razão negra. Lisboa: Antígona, 2014.

McCLINTOCK, Anne. Couro imperial: raça, gênero e sexualidade no embate colonial. Campinas: Editora da Unicamp, 2010.

MELLINO, Miguel. Note sul metodo di Stuart Hall. Althusser, Gramsci e la questione della razza, Décalages, v. 2, p. 1-27, 2016.

MOHANTY, Chandra Talpade. Femminismo senæa fronteire: teoria, differenze, conflitti. Verona: Ombre Corte, 2012.

MOORE, Carlos. Racismo e Sociedade: novas bases epistemológicas para entender o racismo. Belo Horizonte: Nandyala, 2012.

MUNANGA, Kabengele. Rediscutindo a Mestiçagem no Brasil: Identidade Nacional versus Identidade Negra. Belo Horizonte: Autêntica, 2004.

NOGUEIRA, Oracy. Preconceito Racial de Marca e Preconceito Racial de Origem. In: CONGRESSO INTERNACIONAL DOS AMERICANISTAS, 31., São Paulo. Anais... São Paulo: Anhembi, 1955.

NUNES, Míghian D. F. Cadê as crianças negras que estão aqui? O racismo (não) comeu. Latitude, v. 10, p. 383-424, 2016. 
OLIVEIRA, Eduardo de Oliveira e. O mulato, um obstáculo epistemológico. Argumento, Rio de Janeiro, v. 1, n. 3, p. 65-74, 1974.

OLIVEIRA, Fabiana. Um estudo sobre a creche: o que as práticas educativas produæem e revelam sobre a questão racial? 2004. 112 f. Dissertação (Mestrado em Educação) - Universidade Federal de São Carlos, São Carlos, 2004.

ONU. Relatório Internacional do PNUD - Programa das Nações Unidas para o desenvolvimento. Nova York: Publicado Pelo Programa das Nações Unidas Para O Desenvolvimento, 1995.

PISCITELLI, Adriana. G. Sexo Tropical: Comentários sobre gênero, raça e outras categorias de diferenciação social em alguns textos da mídia brasileira. Revista Estudos Feministas, Santa Catarina, v. 6/7, p. 9-35, 1996.

PINTO, Alejandra Aguilar. Reinventando o feminismo: as mulheres indígenas e suas demandas de gênero. In: SEMINÁRIO INTERNACIONAL FAZENDO GÊNERO, 9., Florianópolis, 2010. Anais... Florianópolis: UFSC, 2010. Disponível em: <http://www.fazendogenero.ufsc.br/9/resources/anais/1276200140_ARQUIVO_ApresentFazendo GeneroAleword.pdf>. Acesso em: 21 nov. 2018.

PIOVESAN, Flávia. Apresentação. In: UNIÃO DE MULHERES DE SÃO PAULO. Do silêncio ao grito contra a impunidade. São Paulo: União de Mulheres de São Paulo, 2007. p. 147-187.

PRADO, P. D. As crianças pequenininhas produzem cultura? Considerações sobre educação e cultura infantil em creche. Pro-Posições, v. 10, n. 1, p. 110-118, 10 mar. 2016.

PROENÇA FILHO, Domício P. A trajetória do negro na literatura brasileira. Estudos Avançados, São Paulo, v. 18, n. 50, p. 161-193, 2004.

ROCHA, Edmar José da; ROSEMBERG, Fúlvia. Autodeclaração de cor e/ou raça entre escolares paulistanos(as). Cadernos de Pesquisa, São Paulo, v. 37, n. 132, p. 759-799, Dec. 2007.

ROSA, Susel Oliveira da. Fazer viver e deixar morrer. Revista Aulas (UNICAMP), Campinas, v. 1, n. 3, p. 1-14, mar. 2007. Disponível em: <http://www.unicamp.br/ aulas/>. Acesso em: 21 nov. 2018.

ROSEMBERG, Fúlvia. Educação infantil, classe, raça e gênero. Cadernos de Pesquisa, São Paulo, n. 96, p. 3-86, 1996.

SAFFIOTI, Heleieth. Violência de gênero: o lugar das práxis na construção da subjetividade. Lutas Sociais, São Paulo, n. 2, p. 59-79, 1997.

SAFFIOTI, Heleieth. Gênero, Patriarcado, Violência. São Paulo: Fundação Perseu Abreu; Expressão Popular, 2015.

SANTIAGO, Flávio. Gritos sem palavras: resistências das crianças pequenininhas negras frente ao racismo. Educação em Revista, Belo Horizonte, v. 31, n. 2, p. 129-153, jun. 2015.

SANTIAGO, Flávio; FARIA, Ana Lúcia Goulart de. Da descolonização do pensamento adultocêntrico à educação não sexista desde a creche: por uma pedagogia da não violência. In: TELES, Maria Amélia de Almeida; SANTIAGO, Flávio; FARIA, Ana Lúcia Goulart de (Orgs.). Por que a creche é uma luta das mulheres? Inquietações feministas já demonstram que as crianças pequenas são de responsabilidade de toda a sociedade! São Carlos: Pedro \& João Editores, 2018. p. 246-272. 
SANTOS, Boaventura de Sousa. Um discurso sobre as ciências. 16. ed. Porto: Edições Afrontamento, 2010.

SILVA, Petronilha Beatriz Gonçalves e. Mesa-redonda: Entre os tratados coloniais e a emancipação humana: a luta pelo reconhecimento das diferenças. Campinas, 2015. II Seminário Internacional sobre Infâncias e Pós-colonialismo: Pesquisas em busca de pedagogias descolonizadoras em 26 de Outubro de 2015.

SCOTT, John. W. Gênero: uma categoria útil de análise histórica. Educação e Realidade, Porto Alegre, v. 20, n. 2, p. 71-99, 1995.

SLENES, Robert W. Na senzala uma flor: esperança e recordações na formação da família escrava. Campinas: Editora da Unicamp, 2011.

SOUZA, Ellen Gonzaga de Lima. Percepções de infância de crianças negras por professoras de Educação Infantil. 2012. Dissertação (Mestrado) - Universidade Federal de São Carlos, São Carlos, 2012.

TAGUIEFF, Pierre-André. Il Razæismo: pregiudiæi, teorie, comportamente. Milano: Rafaello Cortina Editore, 1999.

TELES, Maria Amélia de Almeida; Violência contra a Mulher: das primeiras ações à construção de políticas públicas. In: UNIÃO DE MULHERES DE SÃO PAULO. Do Silêncio ao Grito Contra a Impunidade. São Paulo: União de Mulheres de São Paulo, 2007, p. 147-187.

TRINIDAD, Cristiane. Identificação étnico-racial na voz de crianças em espaços de educaşão infantil. 2011. 222 f. Tese (Doutorado) - Pontifícia Universidade Católica de São Paulo, São Paulo, 2011.

WERNECK, Jurema. Nossos passos veem de longe! Movimentos de Mulheres Negras e Estratégias Políticas contra o sexismo e o racismo. Revista da $A B P N$, v. 1, n. 1, mar.-jun. 2010.

WHITAKER, Dulce C. A. Nas franjas do rural-urbano: Meninas entre a tradição e a modernidade. In: FARIA, Ana Lúcia Goulart de (Org.). Dossiê Infância e educação: as meninas, Caderno CEDES, v. XXII, n. 56, p. 07-22, abr. 2002.

Submetido: $18 / 02 / 2019$

Aprovado: $24 / 05 / 2019$ 